\title{
Identifikasi Kuantitas Siswa Yang Miskonsepsi Menggunakan Three Tier- Test Pada Materi Gerak Lurus Beraturan (GLB)
}

\author{
Putri Retno Artiawati ${ }^{1)}$, Riski Muliyani ${ }^{2)}$, Yudi Kurniawan ${ }^{3)}$ \\ ${ }^{1)}$ Prodi Pendidikan Fisika STKIP Singkawang \\ E-mail: putriretnoartiawati@gmail.com \\ ${ }^{2)}$ Prodi Pendidikan Fisika STKIP Singkawang \\ E-mail: kikiriski1012@gmail.com \\ ${ }^{3)}$ Prodi Pendidikan Fisika STKIP Singkawang \\ E-mail: yudikurniawan1012@gmail.com
}

\begin{abstract}
Abstrak. Pembelajaran yang hanya ditekankan pada konsep teoritik saja dapat menyebabkan siswa kurang dalam menguasai konsep ilmiah. Kurangnya penguasaan konsep dapat menyebabkan terjadinya miskonsepsi. Miskonsepsi adalah kekeliruan dalam memahami konsep materi pembelajaran yang dapat menyebabkan ketidakcocokkan antara konsep yang dimiliki oleh pribadi dengan konsep ilmiah. Dengan adanya miskonsepsi yang terjadi, hal tersebut dapat menghambat siswa dalam menerima pengetahuan-pengetahuan yang baru dan dapat pula menghalangi siswa untuk mendapatkan keberhasilan dalam proses pembelajaran.Salah satu faktor lainnya yang terjadi akibat miskonsepsi adalah pengalaman yang tejadi pada kehidupan sehari-hari yang telah dialami siswa, akibat pengalaman yang dialami tersebut konsep yang dimiliki siswa belum tentu sama dengan konsep yang dimiliki oleh ilmuwan.Penelitian ini bertujuan untuk mengidentifikasi kuantitas siswa yang miskonsepsi pada materi Gerak Lurus Beraturan (GLB). Jenis penelitian ini adalah penelitian deskriptif kuantitatif dengan teknik pengambilan sampel adalah purposive sampling. Instrumen penelitian yang digunakan adalah three tier-test. Penggunaan three tier-test bertujuan untuk mengidentifikasi terjadinya miskonsepsi yang terjadi pada siswa. Jawaban yang telah dianalisis selanjutnya akan dihitung dalam bentuk persentase. Terdapat 3 konsep distribusi atau sebaran miskonsepsi pada materi GLB yaitu; 1. Apabila kecepatan suatu benda yang bergerak konstan nilainya besar, maka percepatan benda tersebut juga besar; 2. Kecepatan bernilai negatif itu tidak ada, atau menunjukkan benda diam; 3. Semua benda yang percepatannya nol hanya dalam keadaan diam. Miskonsepsi tertinggi terdapat pada konsep no 1 yaitu apabila kecepatan suatu benda yang bergerak konstan nilainya besar, maka percepatan benda tersebut juga besar. Hasil dari penelitian ini dapat digunakan untuk mencari solusi dalam menurunkan kuantitas siswa yang miskonsepsi khususnya pada materi GLB.
\end{abstract}

Kata Kunci: Kuantitas Siswa yang miskonsepsi, Miskonsepsi, Three tier-test

\section{PENDAHULUAN}

Kesulitan utama siswa dalam mempelajari fisika adalah diakibatkan terjadinya miskonsepsi. Miskonsepsi adalah kekeliruan dalam memahami konsep materi pembelajaran yang dapat menyebabkan ketidakcocokkan antara konsep yang dimiliki oleh pribadi dengan konsep ilmiah atau konsep yang dimiliki oleh ilmuwan. Miskonsepsi dapat terjadi dikarenakan salah menafsirkan proses bahkan fenomena yang terkait satu sama lain yang tidak segera diperbaiki dan berbeda dengan konsep ilmiah [1]. Miskonsepsi diindentifikasikan sebagai konsepsi yang dipegang kuat dan terstruktur secara stabil namun berbeda dengan konsepsi paea ahli [2]. Jika prakonsepsi dan konsepsi sering kali tidak cocok dengan pengetahuan dari ilmuwan maka siswa akan mengalami miskonsepsi [3].

Miskonsepsi merupakan hal yang wajar dalam proses pembentukan pengetahuan bagi seseorang yang sedang belajar [4]. Miskonsepsi yang terjadi terus menerus dan tidak segera diperbaiki maka akan menghambat siswa dalam membentuk konsep ilmiah dan dapat pula mengganggu proses pembelajaran. Hamdani menyatakan bahwa bahwa ada beberapa upaya yang dapat dilakukan untuk mengatasi miskonsepsi antara lain; mengidentidfikasi miskonsepsi, mencari penyebab 


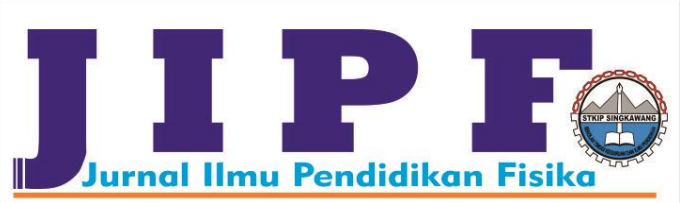

terjadinya miskonsepsi dan menemukan atau mencari solusi untuk memperbaiki miskonsepi [5]. Pada penelitian ini penulis memilih langkah pertama yaitu mengidentifikasi miskonsepsi. Harapan pada penelitian selanjutnya dapat menemukan penyebab maupun solusi untuk memperbaiki miskonsepsi.

\section{METODE}

Jenis penelitian yang digunakan pada penelitian ini adalah deskriptif kuantitatif dan hasil dari penelitian ini adalah gambaran mengenai jumlah kuantitas siswa yang miskonsepsi pada materi Gerak Lurus Beraturan (GLB). Populasi penelitian ini adalah seluruh siswa kelas X di salah satu SMA Negeri Kota Singkawang. Teknik pengambilan sampel pada penelitian ini adalah purposive sampling, teknik pengambilan sampel dengan pertimbangan tertentu yaitu siswa yang telah mempelajari materi Gerak Lurus Beraturan (GLB). Jumlah sampel pada penelitian ini adalah 25 orang siswa.

Three tier-test merupakan satu diantara tes diagnostik yang digunakan untuk mengidentifikasi miskonsepsi [1]. Three tier-test berguna untuk mengetahui jawaban siswa yang salah dan miskonsepsi [6]. Three tier-test memiliki tiga tingkatan yaitu pada tingkat pertama adalah pengujian tentang pengetahuan berupa pilihan ganda. Tingkat kedua, alasan siswa dalam memilih jawaban. Tingkat ketiga adalah keyakinan siswa dalam memilih jawaban [6]. Three tier-test dapat digunakan bagi guru maupun peneliti untuk mengetahui atau mengungkap miskonsepsi yang dialami oleh siswa.

TABEL 1

KePUTUSAn ThreE TIER-Test

\begin{tabular}{cccc}
\hline Jawaban Siswa & Tingkat 1 & Tingkat 2 & Tingkat 3 \\
\hline Konsep Ilmiah & Benar & Benar & Yakin \\
Miskonsepsi & Benar & Salah & Yakin \\
Miskonsepsi & Salah & Benar & Yakin \\
Miskonsepsi & Salah & Salah & Yakin \\
Guess & Benar & Salah & Tidak yakin \\
Guess & Salah & Benar & Tidak yakin \\
Lucky Guess & Benar & Benar & Tidak yakin \\
Lack of & Salah & Salah & Tidak yakin \\
Knowledge & & & \\
\hline
\end{tabular}

Penggunaan three tier-test dapat mempermudah dalam mengungkapkan miskonsepsi yang terjadi
Jurnal Ilmu Pendidikan Fisika

Volum 1 Nomor 1 Maret 2016. Halaman 13-15 p-ISSN: 2477-5959 e-ISSN: 2477-8451

pada siswa. Pada Tabel 2 berikut, merupakan sebaran miskonsepsi yang dialami oleh siswa yang terdiri dari 3 konsep pada materi GLB.

TABEL 2

SEBARAN MISKONSEPSI PADA MATERI GLBB

\begin{tabular}{cl}
\hline No. Konsep & \multicolumn{1}{c}{ Miskonsepsi } \\
\hline Konsep 1 & $\begin{array}{l}\text { Apabila kecepatan suatu benda yang bergerak } \\
\text { konstan nilainya besar, maka percepatan } \\
\text { benda tersebut juga besar } \\
\text { Kecepatan bernilai negatif itu tidak ada, atau } \\
\text { Konsep 2 }\end{array}$ \\
Konsep 3 & $\begin{array}{l}\text { Semua benda yang percepatannya nol hanya } \\
\text { dalam keadaan diam }\end{array}$ \\
\hline
\end{tabular}

\section{HASIL DAN PEMBAHASAN}

Setiap jawaban siswa kemudian dianalisis dan disajikan pada diagram berikut. Persentase kuantitas siswa yang miskonsepsi terdapat pada Gambar 1 berikut.

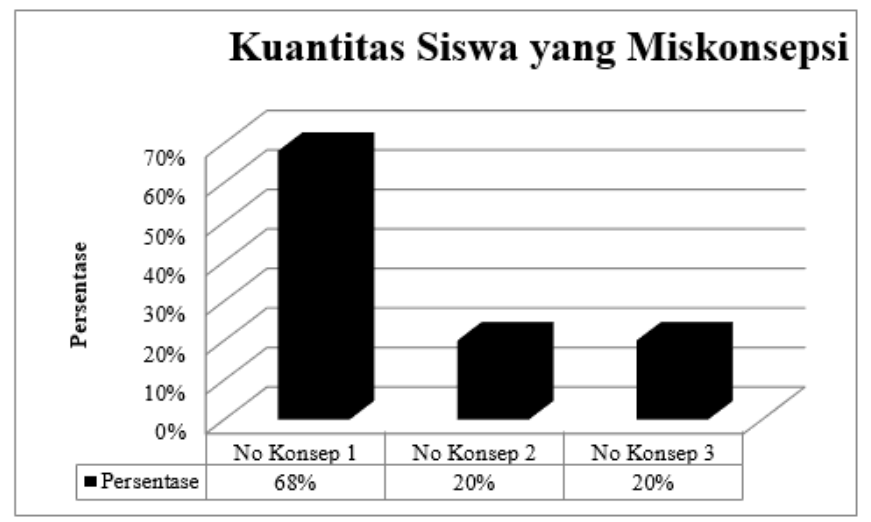

Gambar 1. Kuantitas Siswa yang Miskonsepsi

Identifikasi kuantitas siswa yang miskonsepsi pada penelitian ini menggunakan three tier-test. Berdasarkan Gambar 1 kuantitas siswa yang miskonsepsi dengan persentase $68 \%$ pada konsep no 1 yaitu apabila kecepatan suatu benda yang bergerak konstan nilainya besar, maka percepatan benda tersebut juga besar. Pada GLB benda yang bergerak pada lintasan lurus dengan kecepatan konstan (tetap) dan percepatan nol. Suatu benda yang bergerak konstan memiliki nilai yang besar maka percepatan yang dialami benda adalah nol. Pada GLB kecepatan benda tidak akan berubah terhadap waktu. Kuantitas siswa yang miskonsepsi dengan persentase $20 \%$ pada konsep no 2 yaitu kecepatan bernilai negatif itu tidak ada, atau menunjukkan benda diam. Kecepatan yang bernilai negatif tidak menunjukkan bahwa benda 


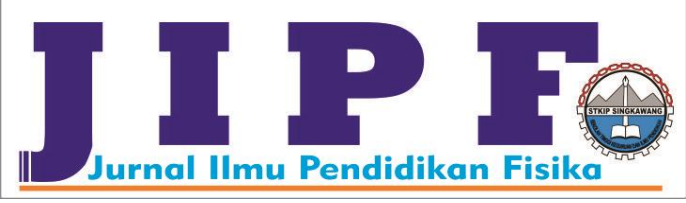

tersebut diam ataupun tidak memiliki kecepatan, melainkan benda tersebut bergerak tetapi berlawanan arah misalnya berlawanan arah dengan sumbu x positif. Sedangkan kuantitas pada konsep no 3 yaitu dengan persentase $20 \%$ yaitu semua benda yang percepatannya nol hanya dalam keadaan diam. Benda yang memiliki percepatan nol mempunyai dua keadaan yaitu diam dan bergerak konstan. Pada Gerak Lurus Beraturan (GLB) ,benda yang bergerak dilintasan lurus dengan kecepatan tetap (konstan) dan percepatan yang dimiliki benda nol. Semua benda yang bergerak dengan kecepatan konstan pada lintasan lurus beraturan memiliki percepatan nol karena tidak ada perubahan kecepatan.

\section{KESIMPULAN DAN SARAN}

\section{A. Kesimpulan}

Berdasarkan dari hasil analisis data yang dilakukan miskonsepsi pada materi Gerak Lurus Beraturan (GLB) terdapat 3 sebaran miskonsepsi. Miskonsepsi terbesar terdapat pada konsep no 1 yaitu sebesar $68 \%$, sedangkan pada konsep no 2 dan 3 memiliki persentase yang sama yaitu sebesar $20 \%$.

\section{B. Saran}

Diharapkan pada penelitian selanjutnya dapat dicarikan penyebab maupun solusi untuk memperbaiki kuantitas siswa yang miskonsepsi.
Jurnal Ilmu Pendidikan Fisika

Volum 1 Nomor 1 Maret 2016. Halaman 13-15 p-ISSN: 2477-5959 e-ISSN: 2477-8451

\section{DAFTAR PUSTAKA}

[1] Muliyani, Riski dan Kaniawati, Ida (2015). "Identification of Quantity Student's Misconception on Hydrostatic Pressure With Three TierTest", GlobalIlluminators Publishing. Vol 2, 2015.

[2] Suhendi, Herni Yuniarti; Kaniawati, Ida; dan Maknun, Johar (2014) "Peningkatan Pemahaman Konsep dan Profil Miskonsepsi Siswa Berdasarkan Hasil Diagnosis Menggunakan Pembelajaran ECIRR Berbantuan Simulasi Virtual dengan Instrument Three-Tier Tes". Prosiding Mathematic and Sciences Forum. 2014.

[3] Pujianto, Agus; Nurjannah; dan Darmadi, I Wayan (2014). "Analisis Konsepsi Siswa pada Konsep Kinematika Gerak Lurus”. Jurnal Pendidikan Fisika Tadulako (JPFT). Vol 1 No 1, 2014.

[4] Hamdani, (2014). "Penerapan Model ECIRR Menggunakan Kombinasi Real Laboratory dan Virtual Laboratory untuk Mereduksi Miskonsepsi Mahasiswa “. Jurnal Visi Ilmu Pendidikan. Vol 6 No 3 , 2014.

[5] Hamdani, (2013). "Deskripsi Miskonsepsi Siswa Tentang KonsepKonsep dalam Rangkaian Listrik". Jurnal Pendidikan Matematika dan IPA. Vol 4 No 1, Januari 2013

[6] Kurniawan, Yudi dan Suhandi, Andi (2015). "The Three-Tier Test for Identification The Quantity of Student's Misconception on Newton's First Law. Globalllluminators Publishing. Vol 2, 2015.

[7] Kurniawan, Yudi; Suhandi, Andi dan Hasanah, Lilik. "The Influence of Implementation of Interactive Lecture Demonstrations (ILD) Conceptual Change Oriented Toward The Decreasing of The Quantity Students That Misconception on The Newton's First Law. AIP Conference Proceedings. 2016. 